\title{
Bisphenol A-an Overview on its Effect on Health and Environment
}

\author{
Ramakrishna MG ${ }^{1}$, Agnishwar Girigoswami ${ }^{1}{ }^{\mathbb{D}}$, Swati Chakraborty ${ }^{2}$, Koyeli Girigoswami ${ }^{1, *}$ (D) \\ 1 Medical Bionanotechnology, Faculty of Allied Health Sciences, Chettinad Hospital and Research Institute, Chettinad \\ Academy of Research and Education, Chettinad Health City, Kelambakkam, 603103, Tamilnadu, India \\ 2 Department of Molecular Biology and Biotechnology, Kanchrapara College (University of Kalyani), Kanchrapara, North \\ 24 Parganas, 743145, Nadia, West Bengal, India \\ * Correspondence: koyelig@ gmail.com (K.G.);
}

Scopus Author ID 23060318900

Received: 9.03.2021; Revised: 6.04.2021; Accepted: 10.04.2021; Published: 19.04.2021

\begin{abstract}
Bisphenol A (BPA) is an organic material used to produce polycarbonate plastics and epoxy resins that are further used to make different plastic bottles and containers for packaging, storage, and food consumption. The possible leaching of BPA from the packaged food products can cause its migration to humans through the consumption of such foods. BPA is commonly known as primary endocrine disruptors that can mimic estrogen hormone action, thereby disrupting the normal estrogenic endocrine function. We have searched the relevant articles in PubMed and Google scholar to write this review and selected the appropriate articles to prepare the manuscript. There are reports on the adverse health effect of BPA on human health as well as in our environment. The routes of exposure of BPA in humans, plants, and aquatic animals were described. The effect on immune response, reproduction in animals and plants as well as neurotoxicity was elaborately discussed. In this review, we have discussed the use of BPA in dairy products and how it affects health and the environment.
\end{abstract}

Keywords: bisphenol A; endocrine disrupter; BPA toxicity; immunomodulatory effect; reproductive impairment.

(C) 2021 by the authors. This article is an open-access article distributed under the terms and conditions of the Creative Commons Attribution (CC BY) license (https://creativecommons.org/licenses/by/4.0/).

\section{Introduction}

Bisphenol A (BPA) is an organic material used for manufacturing epoxy resins, polycarbonate, and polyvinyl chloride plastics and was first produced in the year 1891 but was commonly used from the year 1930 when scientists created polycarbonate plastic using BPA [1]. The polycarbonate plastics and epoxy resins are used in milk bottles, water bottles, baby bottles, plastic plates/cups, paints, coatings, primers, and dairy products packaging. The BPA present in this type of plastics moves from the packaging material to the dairy products eventually [2]. This contact with food material is due to heating, overuse, contact with an acidic or alkaline substance, and microwave exposure, leading to BPA intake and the food material. Some studies have shown that contact with food results in the presence of non-conjugated BPA in individual adult serum and fetuses [3]. A reported data showed that nearly $34 \%$ of the estrogenic exposure was caused by BPA activity in New Zealand. The analytical methods for BPA detection in food include UV visible spectroscopy, fluorescence spectroscopy, mass spectrometry, diode array detection, and electrochemical detection [4]. BPA detection using nanotechnology has also been exploited by designing an electrochemical sensor with modified 
graphite nanostructures, phosphotungstic acid, and Nafion coating over the glassy carbon electrode [5].

\section{Exposure of BPA in Humans}

BPA is added to toys, plastic eating utensils, eyeglasses, reusable containers for food storage, food packaging, office products, and even in the thermal receipt paper to prevent contamination and extend shelf life. Once these products are released into the environment, BPA enters the body through skin contact, ingestion, or inhalation [1]. BPA has a low half-life of 1-10 days in soil, even then, it is an important pollutant since it is omnipresent [6], and with its widespread usage, air, water, and soil become possible routes of exposure to BPA. Workers in the synthesis of BPA, epoxy resins PVC, thermal paper, and tetrabromobisphenol-A are very highly exposed to BPA. The use of BPA in the industry and thermal paper recycling has led to high BPA quantities being leached into the environment contaminating soil, atmosphere, and aquatic regions. In water, the BPA is degraded by the aquatic microorganisms, and in the air, it gets degraded by the photodecomposition, which reduces the presence of BPA to lower levels. Food exposure of BPA is prominently from canned food and beverages, which consist of BPA in the PVC plastic containers. BPA exposure from food is the most problematic route because it gets exposed to many people in trace amounts without getting detected for a long time [3]. Studies done for the concentration of BPA in the air are limited, but a study done in China showed that the BPA concentration in air of epoxy resin factories $\left(492 \mu \mathrm{g} / \mathrm{m}^{3}\right)$ is higher than BPA factories $\left(50.8 \mu \mathrm{g} / \mathrm{m}^{3}\right)$ [6].

BPA is related to chronic kidney disease and has been reviewed earlier [7]. A study done earlier demonstrated that adults on maintenance of hemodialysis had 6 times higher concentrations of BPA than a normal adult because the dialysis procedure used BPA containing accessories. The study focused on plasma BPA levels present in the patients with impaired renal functions, and the maintenance dialysis has influenced the concentration of BPA present in the plasma. In stage 3 chronic kidney disease, the increase in plasma BPA was evident. The study was performed on 152 prevalent patients with chronic kidney disease [8]. BPA was found in the range of 0.001 to $82.7 \mu \mathrm{g} / \mathrm{g}$ in paper currencies in a study performed with paper currencies collected from 21 countries. It was also prominent that BPA exposure through thermal paper was more common than exposure from resin or plastic polymerized from BPA. Thermal papers refer to tickets, packaged items, labels, ATM receipts etc., and the contact goes from the hand then to the mouth [9]. BPA was also present in a number of magazines, newspapers, cigarette filters, paper currency, flyers, luggage tags, facial tissue, recycled paper towels, napkins, printing ink, toilet paper, and business cards.

BPA gets quickly eliminated from the body at small doses, but it is not easily eliminated from the body at high doses and gets accumulated in the body. It is metabolized in the liver and intestines and is eliminated through urine in humans [10]. When the alimentary canal gets exposed, it is absorbed by the gastrointestinal tract and is transported to the liver, where it gets metabolized by glucuronidation (90\%) and also by sulfation (10\%). After its metabolism, the BPA gets broken down into inactive forms that are known as glucuronide BPA and sulfated BPA [3]. The health effects of BPA is of great concern for many years, and a number of studies have discussed the harmful effects of BPA. 


\section{Health Effects of BPA}

Many studies were done on the topic of BPA health effects from the 1990s to the 2000s, and most of the studies showed some form of toxicity, but there was some uncertainty present due to the critical data gaps. With the increasing worries about the toxicity of BPA, the National Institute of Environmental Health Sciences (NIEHS) started developing a targeted BPA research program in the mid-2000s [11]. Thyroid function gets disrupted by BPA because BPA is a known endocrine disrupter, and studies have shown a significant association between higher urinary BPA levels and higher T3 and lower TSH. A study done in adults and children showed that immune function decreases with the increase in BPA exposure. Increased BPA levels also cause albuminuria. Albuminuria refers to the increase in the albumin level in the urine. It indicates endothelial dysfunction in the kidney and is a predictor of cardiovascular diseases. There are not many reported disorders related to gene expression directly related to the increased levels of BPA, but some studies found BPA was associated with gene-related diseases [12]. BPA is also seen to reduce sperm quality in humans and lead to behavioral and cognitive impairments in children [13,14]. BPA is seen to have a profound impact on ovaries as well. Studies performed on animals and humans have shown that BPA influences the onset of meiosis in ovaries. A study done by Lenie et al. showed how BPA also interferes with germ cell nest disintegration in animal models [15].

When BPA-containing products were used as dental composite resin, they were seen to cause occupational photosensitive dermatitis and allergies [6]. A study was done in 2008 with 1455 adults from the age group of 18-74 years. The BPA level was measured in urine and urine creatinine concentrations. The study showed that higher urinary BPA concentrations were associated with cardiovascular diseases. This was done using regression models that were adjusted according to age, sex, race/ethnicity, education, income, smoking, body mass index, waist circumference, and urinary creatinine concentration. Type- 2 diabetes has been associated with BPA in many human studies. Adults with type- 2 diabetes showed a higher level of BPA concentration in their urine, indicating a significant relationship between elevated BPA concentrations and type- 2 diabetes [16]. In 2012, an analysis from 745 participants was carried out. Estimations of the associations were executed between urinary BPA levels and peripheral arterial disease (ankle-brachial index $<0.9, \mathrm{n}=63$ ) using logistic regression models adjusted for potential confounder (age, sex, race/ethnicity, education, smoking, body mass index, diabetes mellitus, hypertension, urinary creatinine, estimated glomerular filtration rate, and serum cholesterol levels). The results showed a significant association of urinary BPA levels before and after adjusting for different confounders [11]. Many review reports are available where there is an elaborate description of humans' health and neurological effects after exposure to BPA [17-22] and their decomposition using microorganisms [23].

The effect of human health after consuming animal and plant products containing BPA was discussed earlier. The BPA consumption from meat was three times lower in women, pregnant women, children, and adults compared to previous reports. The other potential sources were the conjugated BPA (BPA-monoglucuronide, BPA-diglucuronide, and sulfate forms, which were also aimed to be estimated to follow up the toxicity [24]. The carcinogenic effect which has been observed for ovarian and breast cancer has also been reviewed. Being an estrogenmimicking compound, BPA can activate the estrogenic receptors $\alpha$ and $\beta$, and it can regulate various cellular processes like proliferation, apoptosis, cell migration, etc. The genes that can modulate female cancers, like the multiple oncogenic pathways of signaling- PI3K/AKT, STAT3 and 
MAPK are triggered by exposure to BPA. Some other modifications that BPA can execute in females and males reproductive system are induction of benign lesions like ovarian cyst development, developing endometrial hyperplasia, and enhancing the mammary gland cells' ductal density along with preneoplastic lesions [25]. In males, BPA can interact with GPR30 and bind with androgen receptors like C/EBP, PPAR, Nrf2, HAND2, and HOX and impair the reproductive function. These receptors are also involved in the action of BPA in the cardiovascular system, fat homeostasis, cancer, and liver homeostasis [26]. The decreased male fertility involving cryptorchidism, testicular dysgenesis, and cancer caused due to the effect of BPA has been discussed by Matuszczak et al. [27]. Earlier reports exist on the underlying mechanisms involved in the toxicity of multiple organs induced by BPA. The different receptor pathways were elaborately discussed with the disruption of the neuroendocrine system, enzyme inhibition, genotoxic and epigenetic mechanism, and how BPA modulates the immune and inflammatory responses [28].

BPA and its analogs can contribute significantly to the obesity of children and adults and is known to be an obesogen. The weight gain happens due to the activation of certain nuclear transcription factors at the molecular level like peroxisome proliferator-activated receptor (PPAR) alpha, delta, gamma, and some steroid hormone receptors regulate the proliferation of the adipocytes and also modulate their differentiation. They influence lipid metabolism, which further affects the composition of our body [29]. A suitable model system is necessary to study the effect of BPA, the outcome of which can be extrapolated for humans. A group of researchers has explored the different model systems used to assess BPA toxicity, like zebrafish, rodents, nematodes, crustaceans, Drosophila, and echinoderms [30].

The tentative action mechanism of BPA in the rat prostate epithelium was explored by culturing the ventral prostate epithelial cells in vitro, and the BPA effects were studied. The cell viability, apoptosis, and the androgen receptor (AR) expressions were monitored, and results demonstrated that $0.01-1 \mathrm{nM}$ of BPA promoted the growth of cells, $1 \mathrm{nM}$ contributing the maximum. No morphological changes were observed in the cells treated with BPA with lower apoptosis than the control group. On the other hand, the ER $\alpha$ and ER $\beta$ expression increased, although the AR level decreased. Thus, it was concluded that BPA exposure increased prostate cell proliferation by enhancing the estrogenic receptor expression and decreasing AR expression. There was also a decrease in the apoptotic mode of cell death [31]. In another study involving the BPA effect on the male reproductive system, the male mice were exposed to BPA at the time of the fetal-perinatal period, i.e., from 10 days post coitum till 31 days postpartum. The impact on gamete health was explored at adulthood (78 days of age) due to the early-life BPA exposure. The motility of spermatozoa, the acquisition of the sperm motility, and the chromatin condensation of spermatozoa were monitored for both control and BPA treated mice. The results showed that during the epididymal spermatozoa maturation, there was a harmful effect on the viability as well as motility of the sperms. There was also chromatin condensation observed, demonstrating the hazardous effect of BPA on the male reproductive system [32]. Figure 1 summarises the health effects impacted by BPA.

Apart from exerting a spectrum of health hazards in humans, BPA also poses a threat to the environment. In the next section, we shall discuss some important effects of BPA in our environment. 


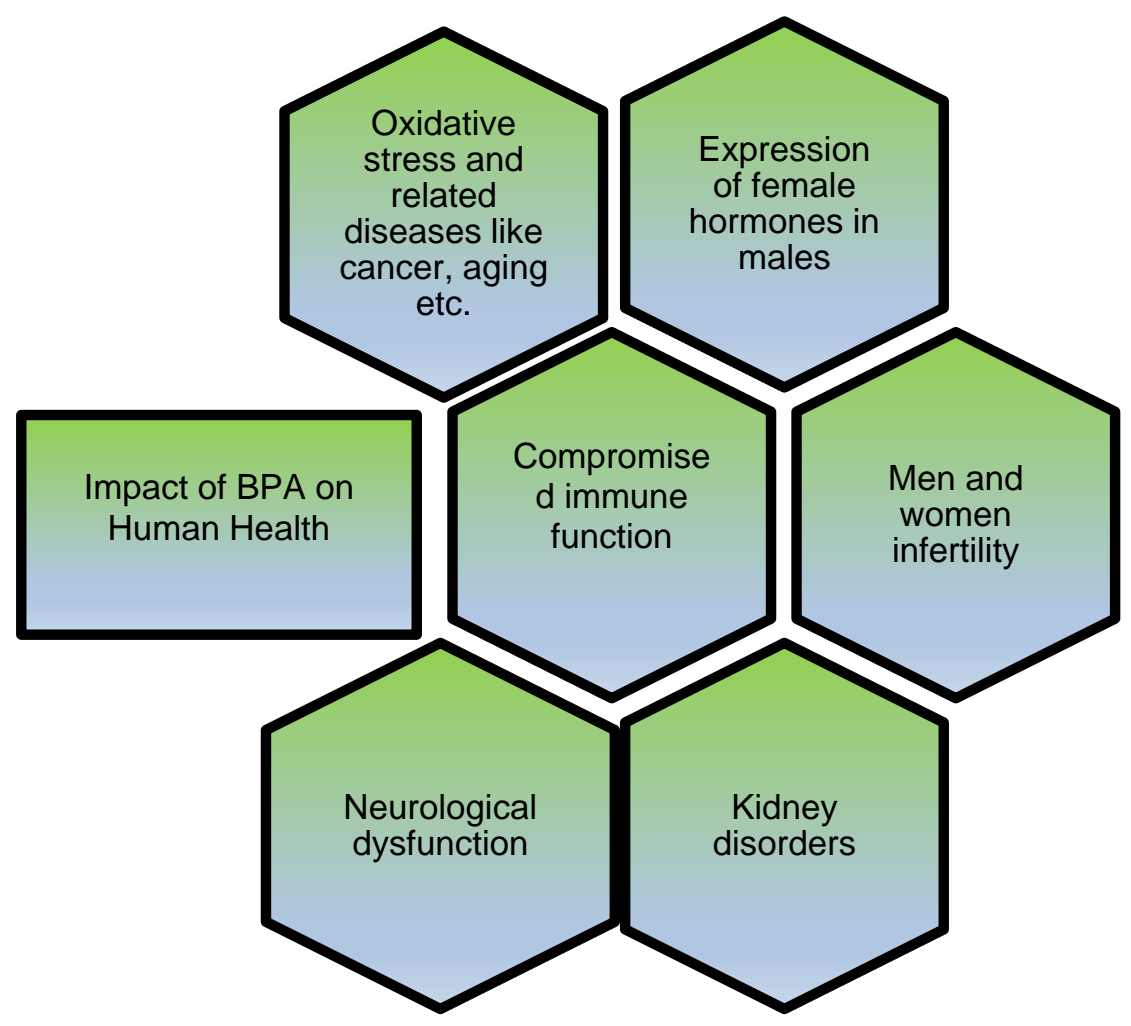

Figure 1. The different impacts of BPA on human health.

\section{Effect of BPA on Environment}

BPA is not a native component of the environment, but immense use of plastic material that contains BPA as an industrial component makes it a global ingredient of the environment. The environment is contaminated by BPA pollution through diverse pathways, such as the effluent waste of the BPA manufacturer and BPA-containing product mixed with the environment. Deposition of the plastic products into rivers and marine water contaminate the aquatic environment with BPA [33-34]. BPA concentration is noticeable in samples from the Urban Community of Quebec wastewater treatment plant located in Quebec (Canada) [35]. Human beings regularly consume BPA due to the use of different types of plastic products, which gets digested further disposing of BPA in sewage water, and this sewage now becomes the source of BPA in the environment. It is observed that the wastewater sludge is carrying much more BPA than wastewater [36]. Sediment concentrations of BPA in Asia are much more compared to Europe [33]. Breakdown of plastic, discharge of garbage in bulk, combustion of household waste, etc., are major BPA contributors to soil, water, and air. All these processes are associated with BPA pollution. BPA is a biodegradable component and can be degraded by aerobic bacteria with an environmental half-life between 4.5 and 4.7 days. However, the biodegradation of BPA becomes slow in oxygen-depleted conditions, and as a result, it gets deposited in the anaerobic sediments [37, 38]. BPA gets partitioned into water and tends to a low rate of evaporation because of its moderately high water solubility $(120 \mathrm{mg} / \mathrm{l})$ with low Kow values (partitioning coefficient in octane and water) of 2.20 [39]. When BPA comes in contact with soil, it is trapped due to the high value of soil-water partition coefficient of 314 to 1524. Inadequate information regarding BPA pollution in the environment is upsetting because BPA can act as an endocrine disruptor. It is harmful to the biological system above the upper limit concentration. The maximum limit of concentration for drinking water is $1.5 \mathrm{mg} / \mathrm{L}$, according to the U.S. Environmental Protection Agency [40]. Plant growth and aquatic ecosystems are influenced by polluted soil, water, air, and plant roots exposed to BPA through 
direct contact with soil from where it spreads to all the plant parts. On the other hand, estrogenic activity has a negative effect on aquatic animals' reproductive systems.

\subsection{Effect of BPA on plants.}

The growth and development of plants are dependent on different signaling substances known as plant hormones which govern the developmental process with systematic coordination. Some of the plant hormones responsible for the development are cytokinin, auxin, abscisic acid, ethylene, brassinosteroid, jasmonic acid, gibberellin and strigolactone, which may get affected when exposed to environmentally hazardous substances like BPA [41]. Qiu et al. observed the root growth of soybean (Glycine max L.) plants at three growth stagesseedling stage, the flowering and podding stage, and the seed-filling stage. They measured the fresh weight, dry weight, length, and volume of the roots in BPA presence at various concentrations. The impact of BPA was also investigated by assessing the switches in endogenous hormone concentrations of the root. Plant growth and morphogenesis are controlled mainly by endogenous hormones like indole-3-acetic acid (IAA), Zeatin (ZT), gibberellic acid (GA3), abscisic acid (ABA), and ethylene (ETH) [42]. The results showed that BPA at low concentration $(1.5 \mathrm{mg} / \mathrm{L})$ improved root growth except at the seed-filling stage, and the effect was maximized at the seedling stage. Content of IAA in root increased at low concentration, but the result was reversed with the rise in BPA amount. Medium to high concentrations of BPA repressed root growth, and the effect was most adverse for seedlings. ABA concentration was almost constant at a low concentration at all the stages, whereas, gradual increment of mass of BPA hiked the content of ABA in soybean root [43]. ABA, an important phytohormone, plays a vital role in different stress conditions like thermal, heavy metal, radiation, salt stress, etc., in plants [44]. The findings of the study done by Li et al., 2018 are summarized in Table 1 [43].

Table 1. The effect on root growth and the different endogenous hormone load after exposure to different concentrations of BPA.

\begin{tabular}{|c|c|c|}
\hline \\
\hline $\begin{array}{c}\text { Concentration of } \\
\text { BPA }\end{array}$ & Effect on root growth & Effect on endogenous hormone load \\
\hline $1.5 \mathrm{mg} / \mathrm{L}$ & $\begin{array}{l}\text { At seedling stage: } \\
\text { Hiked in fresh weight - } 3.14 \% \text {, in dry weight- } \\
23.80 \% \text {, in length- } 4.05 \% \text { and in volume- } 6.74 \\
\% \text { with respect to control (BPA untreated). } \\
\text { Slight increase in the surface area of the root. } \\
\text { At the flowering and podding stage: } \\
\text { Hike in fresh weight, dry weight, length, and } \\
\text { volume was observed but less than a seedling } \\
\text { stage. } \\
\text { At the seed-filling stage } \\
\text { Ineffective on root growth. }\end{array}$ & $\begin{array}{l}\text { At seedling stage: } \\
\text { Hike in IAA content- } 5.00 \% \text {, in (ZT) content- } 23 \\
\% \\
\text { Decrease in ETH content- } 25.6 \% \text {, in GA3 } \\
\text { concentration- } 12.7 \% \text {. } \\
\text { No change in ABA concentration } \\
\text { At the flowering and podding stage: } \\
\text { Increased IAA content- } 3.00 \% \\
\text { Decrease in ETH content- } 17.6 \% \\
\text { ABA concentration was almost constant. } \\
\text { At the seed-filling stage } \\
\text { A slight decrease in IAA and GA3, ZT } \\
\text { concentration. } \\
\text { Decrease in ETH content- } 12.9 \% \text {. } \\
\text { ABA concentration was unchanged. }\end{array}$ \\
\hline 6.0 and $12.0 \mathrm{mg} / \mathrm{L}$ & $\begin{array}{l}\text { Decrease in fresh weight, dry weight, length, } \\
\text { and surface area. } \\
\text { Most lowering effects of indices were observed } \\
\text { at the seedling stage. }\end{array}$ & $\begin{array}{l}\text { Lowering in the content of IAA, GA3, ZT at its } \\
\text { maximum at the seedling stage compared to } \\
\text { flowering, podding stage and seed filing stage. } \\
\text { However, ABA concentration gradually increased } \\
\text { with increased BPA concentration at all of the } \\
\text { three stages under experiment. }\end{array}$ \\
\hline
\end{tabular}


According to Jiao et al., a low concentration $(1.5 \mathrm{mg} / \mathrm{L})$ of BPA helps to enhance the chlorophyll amount as well as the rate of photosynthesis by increasing the number of essential enzymes and intermediates in chlorophyll synthesis at different stages of growth of soybean plant. On the other hand, medium to a higher concentration of BPA (7- $50 \mathrm{mg} / \mathrm{L})$ gives an adverse effect by reducing the activities of main enzymes. The intermediate BPA concentration blocked the chlorophyll synthesis, and as a result, the rate of photosynthesis decreased. The inhibitory effect of BPA, based on chlorophyll content, was not similar at all stages of growth and the seedling stage was mostly affected [45]. The summary of results showing the effect on chlorophyll synthesis is given in table 2 .

Table 2. The effect of different concentrations of BPA on chlorophyll synthesis in the soybean plant.

\begin{tabular}{l|l} 
Concentration of BPA & \multicolumn{1}{c}{ Effect on chlorophyll synthesis } \\
\hline $1.5 \mathrm{mg} / \mathrm{L}$ & $\begin{array}{l}\text { a. Enhancement in the actions of essential enzymes- porphobilinogen deaminase, 5-aminolaevulinic } \\
\text { acid dehydratase, magnesium chelatase, uroporphyrinogen III synthase. } \\
\text { b. Hike in the amount of intermediates in chlorophyll synthesis- 5-aminolevulinic acid, } \\
\text { porphobilinogen, protoporphyrin IX, magnesium protoporphyrin and protochlorophyllide at } \\
\text { different growth stages. } \\
\text { c. An overall enhancement in chlorophyll content and net photosynthetic rate. }\end{array}$ \\
\hline $7.00-50.0 \mathrm{mg} / \mathrm{L}$ & $\begin{array}{l}\text { a. Inhibitory effect on the working of the key enzymes. } \\
\text { b. Suppressed the 5-aminolevulinic acid and porphobilinogen, thereby reduced the synthesis of } \\
\text { remaining intermediates. } \\
\text { c. Ultimately lowering in the content of chlorophyll. }\end{array}$
\end{tabular}

\subsection{Effect of BPA exposure in aquatic animals.}

A complete meta-analysis on the effect of BPA in aquatic organisms has shown that it negatively affects the developmental process across all of the texas [46]. Researchers have elaborately described the various effects of BPA on aquatic animals [47], such as fish, aquatic reptiles, amphibians, and mammals exposed to BPA at high concentrations, ethinyl estradiol (EE2) and estrogen in the form of birth control pills. They have explored that BPA is detectable in all the water bodies, and the high BPA concentrations have affected the sexual and neural development of the above-mentioned species, including the sex reversal effect of males to females. The opposite sex mate attraction was also depleted, and the male reproductive capacity was compromised. It was predicted that the genetic defects might get transmitted to their offspring through their sperm epigenome. In the end, the transmission of these effects to humans through biomagnification was also discussed [48]. The developmental effect on aquatic vertebrates and invertebrates due to exposure to BPA was also studied. In the nonmammalian vertebrates of particular aquatic animals, there was major development as well as reproductive defect manifested by male hormones reduction, testicular cell death, spermatogenesis and egg production inhibition, reduction in sperm density and motility, and absence of ovulation. The sex ratio was impaired, and there was a negative effect on the immune function as well as metabolism. In the case of invertebrate organisms like daphnids, not too many studies have been reported. There was a significant effect on the development and reproductive system found in other invertebrate species, copepods, and mollusks [49]. The animals in the wildlife also consume water from the different water bodies contaminated with BPA. BPA concentrations in stream/river water were found to be less than $21 \mu \mathrm{g} / \mathrm{L}$, and its concentration in landfill leachates was less than $17.2 \mathrm{mg} / \mathrm{L}$. There are known reports that BPA can induce feminization at the time of gonadal ontogeny in the fishes, birds, and reptiles, but the concentration required to make such changes should exceed the amount present in the environment. In adult fishes, BPA was found to affect spermatogenesis and can stimulate 
vitellogenin synthesis, although the mechanism of action was not explored yet [50]. The effect of plasticizers and BPA on different animals, especially aquatic animals, demonstrated the alteration in thyroid hormone and growth hormones. There was interference in the reproduction by decreased mitochondrial membrane cholesterol transport, which resulted in reduced steroidogenesis.

Activation of some receptors like peroxisome proliferator-activated receptors was observed, which enhanced the oxidation of fatty acids, thereby reducing the capacity to overcome the oxidative stress leading to malformation of reproductive organs and decreased fertility and reproductive defects [51]. In a review by Oehlmann et al., exposure to BPA has adverse effects on the reproduction of aquatic organisms like mollusks, crustaceans, insects, fishes, amphibians, and many other organisms [52]. Studies were conducted on Xenopus laevis (African clawed frog) and Acartiatonsa (calanoid copepod, Crustacea) to investigate the organism's full life cycle and the thyroid system when exposed to BPA. Molluscs, crustaceans, and amphibians appeared to be especially sensitive to BPA and other plasticizers, and the biological effects were observed at environmentally relevant exposures in the low ng $1^{-1}$ to $\mu \mathrm{g}$ $1^{-1}$ range. The effect of BPA on snails has shown that there was the generation of superfemales that possessed additional female organs, malformation to a large extent in the pallial oviduct, enlargement of accessory sex glands. There was stimulation in egg and clutch production that resulted in the mortality of the females [52-54]. Some of the studies are given in table 3 discussing the effect of BPA in different aquatic organisms.

Table 3. The effect of BPA exposure in different types of aquatic organisms.

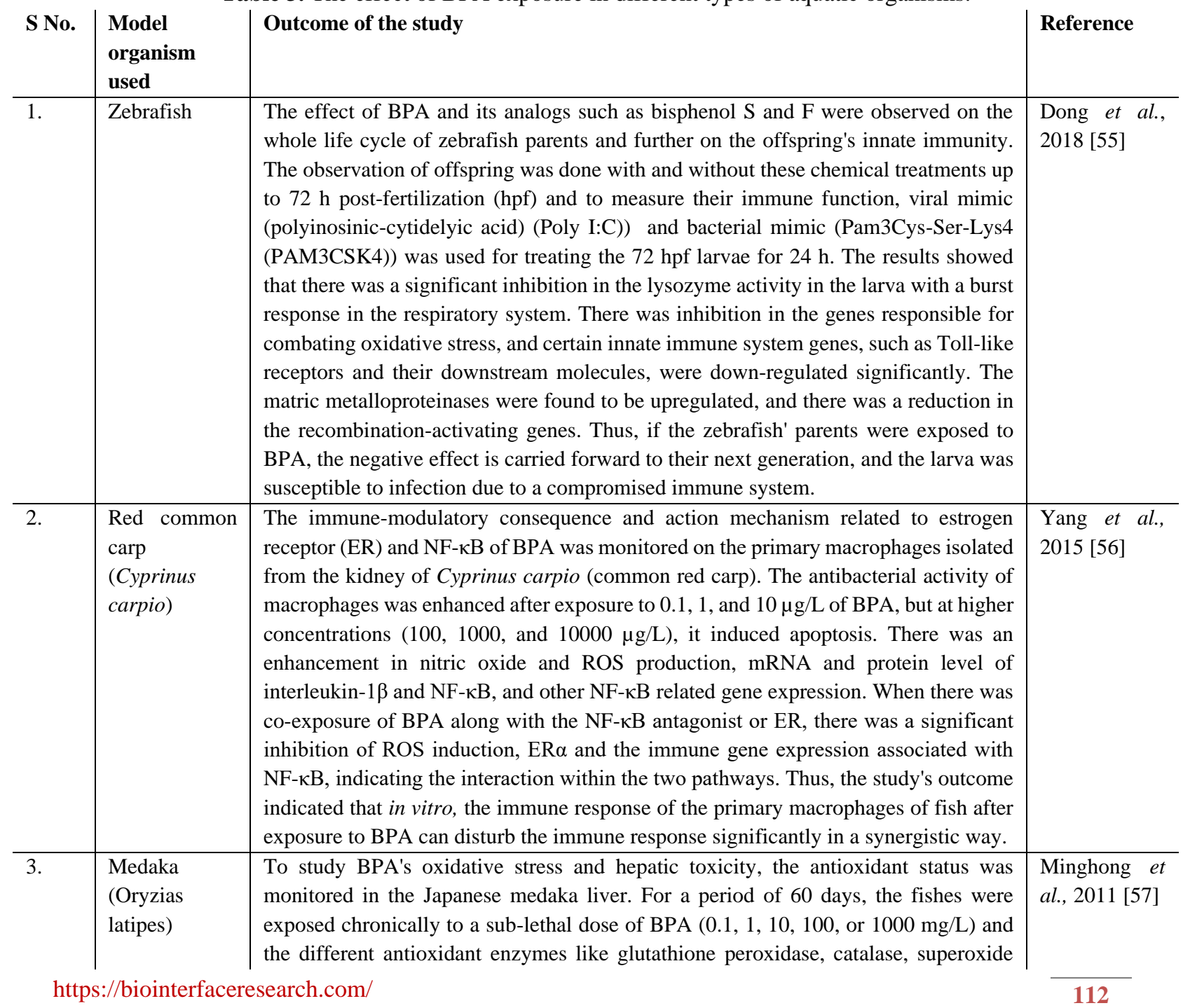




\begin{tabular}{|c|c|c|c|}
\hline S No. & $\begin{array}{l}\text { Model } \\
\text { organism } \\
\text { used }\end{array}$ & Outcome of the study & Reference \\
\hline & & $\begin{array}{l}\text { dismutase, reduced glutathione, and glutathione S- transferase was assayed. The } \\
\text { results showed that all these antioxidant parameters were induced after chronic BPA } \\
\text { exposure, and catalase was the first to get induced after exposure to } 10 \mathrm{mg} / \mathrm{L} \text { of BPA. } \\
\text { This indicated that oxidative stress was induced, and catalase can be an early marker } \\
\text { for detecting BPA-induced oxidative stress in aquatic environment organisms. }\end{array}$ & \\
\hline 4. & $\begin{array}{l}\text { Daphnia } \\
\text { magna, and } \\
\text { Chironomus } \\
\text { riparius }\end{array}$ & $\begin{array}{l}\text { Nonylphenol (NP) along with BPA was explored for their genotoxicity and ecotoxicity } \\
\text { using Daphnia magna and Chironomus riparius. There was DNA damage found after } \\
\text { exposure to BPA in D. magna. }\end{array}$ & $\begin{array}{l}\text { Park et al., } \\
2009[58]\end{array}$ \\
\hline 5. & $\begin{array}{l}\text { Chironomus } \\
\text { riparius larvae }\end{array}$ & $\begin{array}{l}\text { The effect of BPA on aquatic invertebrate Chironomus riparius larvae gene expression } \\
\text { was studied. The housekeeping genes, stress-induced as well as hormone-related genes } \\
\text { were assessed by Northern blot or semi-quantitative RT-PCR and the results revealed } \\
\text { that low dose ( } 3 \mathrm{mg} / \mathrm{L} \text { ) exposure to BPA for } 12 \text { to } 24 \mathrm{~h} \text { did not alter the rRNA or } \\
\text { mRNA levels of L11 or L13 ribosomal proteins, the housekeeping genes responsible } \\
\text { for ribosome biosynthesis. No expression of HSP70 gene was observed after BPA } \\
\text { treatment, but there was a significant increase in the mRNA level of ecdysone receptor } \\
\text { (EcR). The study's outcome indicated that the ecdysone receptor gene expression } \\
\text { elevation was affecting the endocrine system of the insects directly and there was a } \\
\text { common mechanism of action of BPA toxicity in both vertebrates and invertebrates } \\
\text { through steroid hormone-receptor interaction. }\end{array}$ & 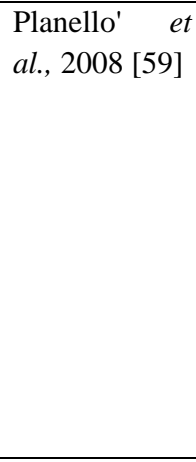 \\
\hline 6. & $\begin{array}{l}\text { Goldfish } \\
\text { (Carassius } \\
\text { auratus) }\end{array}$ & $\begin{array}{l}\text { The influence of BPA on the reproductive system was observed in the ovary and testis } \\
\text { development of goldfish, and the gonadosomatic index (GSI) and gonadal histology } \\
\text { were investigated. The BPA was shown to diminish ovarian maturation, which } \\
\text { reversed back after withdrawal of BPA treatment. The hypothalamic-pituitary-gonad } \\
\text { (HPG) axis- associated genes fshb, sgnrh and lhb was significantly diminished in the } \\
\text { female fish treated with BPA was no change in the level of sex steroid hormone. There } \\
\text { was no TUNEL, and PCNA staining observed in the ovary, indicating a reduction in } \\
\text { ovarian maturity mediated by the HPG axis. In the case of male fish, TUNEL staining } \\
\text { was observed in germ cells exposed to } 1 \mu \mathrm{g} / \mathrm{L} \text { of BPA whereas in Leydig cells, the dose } \\
\text { of BPA required was } 50-500 \mu \mathrm{g} / \mathrm{L} \text {. } 11-\mathrm{KT} \text { levels were found to be decreased after } 50- \\
500 \mu \mathrm{g} / \mathrm{L} \text { BPA exposure, but the HPG associated genes were not altered. The results } \\
\text { revealed that BPA could attenuate testis' maturation via germ cell and Leydig cell } \\
\text { apoptosis, thereby downregulating } 11-\mathrm{KT} \text { levels, which is responsible for disrupting } \\
\text { spermatogenesis. }\end{array}$ & $\begin{array}{l}\text { Wang et al., } \\
2019[60]\end{array}$ \\
\hline 7. & $\begin{array}{l}\text { Medaka } \\
\text { (Oryzias } \\
\text { latipes) }\end{array}$ & $\begin{array}{l}\text { Chronic exposure of BPA at a low dose }(10 \mu \mathrm{g} / \mathrm{L}) \text { for } 60 \text { days in the fish liver was } \\
\text { followed by gene expression study at the transcription level. Immune-associated } \\
\text { genes, such as MHC class I, hepcidin-like precursor, complement component and } \\
\text { factors, alpha-2-macroglobulin, and novel immune-type receptor r6 isoform were } \\
\text { assessed using real-time PCR analysis, and there was a significant upregulation in all } \\
\text { the genes studied. } \\
\text { This suggested that there was an immunomodulatory response observed in fish after } \\
\text { chronic low dose exposure to sub-lethal concentrations of BPA. }\end{array}$ & $\begin{array}{l}\text { Qiu et al., } \\
2016 \text { (a) [61] }\end{array}$ \\
\hline 8. & $\begin{array}{l}\text { Red common } \\
\text { carp } \\
\text { (Cyprinus } \\
\text { carpio) }\end{array}$ & $\begin{array}{l}\text { Long-term exposure of BPA on common carp was studied after exposing the fishes } \\
\text { for } 30 \text { days with different BPA concentrations }(0.1,1,10,100 \text {, and } 1000 \mu \mathrm{g} / \mathrm{L}) \text {, and } \\
\text { the immunological parameters, as well as oxidative stress markers, were monitored in } \\
\text { the liver and serum. The hepatosomatic index increased significantly at the highest } \\
\text { dose }(1000 \mu \mathrm{g} / \mathrm{L}) \text {, indicating the high BPA accumulation in the bile. Lipid } \\
\text { peroxidation increased in the liver with decreased antioxidant enzyme levels (catalase, } \\
\text { superoxide dismutase, and glutathione peroxidase). There was an increase in the level } \\
\text { of Lysozyme and C-reaction protein in serum after exposure to low doses, but they } \\
\text { were suppressed significantly at higher doses. The immunoglobulin } \mathrm{M} \text {, alkaline } \\
\text { phosphatase, and complement component } 3 \text { were enhanced significantly in liver and } \\
\text { serum after low dose BPA exposure }(0.1 \text { and } 1 \mu \mathrm{g} / \mathrm{L}) \text {. The study showed that even a } \\
\text { low dose of BPA exposure could cause significant immunosuppression in the fish for } \\
\text { the long term. }\end{array}$ & $\begin{array}{l}\text { Qiu et al., } \\
2016 \text { (b) [62] }\end{array}$ \\
\hline 9. & $\begin{array}{l}\text { Minnow } \\
\text { (Gobiocypris } \\
\text { rarus) }\end{array}$ & $\begin{array}{l}\text { A high dose of BPA }(1225 \text { and } 1000 \mu \mathrm{g} / \mathrm{L}) \text { was exposed to minnow (Gobiocypris } \\
\text { rarus) larvae for } 7 \text { days, and the different inflammatory markers, such as nitric oxide } \\
\text { (NO) and ROS production, alteration in the iNOS mRNA and the different TLRs- }\end{array}$ & $\begin{array}{l}\text { Tao et al., } \\
2016[63]\end{array}$ \\
\hline
\end{tabular}

https://biointerfaceresearch.com/ 


\begin{tabular}{|c|c|c|c|}
\hline S No. & $\begin{array}{l}\text { Model } \\
\text { organism } \\
\text { used }\end{array}$ & Outcome of the study & Reference \\
\hline & & $\begin{array}{l}\text { associated immune gene expression was assessed. There was a significant upregulation } \\
\text { in all the above-mentioned parameters and genes, indicating the role of oxidative stress } \\
\text { in influencing the } \mathrm{T} \text { lymphocyte function and decrease the cytokine gene expression } \\
\text { at the transcriptional level. There was } \mathrm{H}_{2} \mathrm{O}_{2} \text { overproduction which induced oxidative } \\
\text { stress, thereby suppressing TLR } 4 / \mathrm{NF}-\mathrm{\kappa B} \text { signaling resulting in immunosuppression of } \\
\text { the fish larvae. }\end{array}$ & \\
\hline 10. & $\begin{array}{l}\text { Xenopus } \\
\text { laevis } \\
\text { embryos }\end{array}$ & $\begin{array}{l}\text { The influence of different environmental toxicants like BPA, nonylphenol (NP), and } \\
\text { 17b-estradiol (E2) was observed in developing Xenopus leavis embryos. The exposure } \\
\text { time of the above toxicants was between } 3 \mathrm{hpf} \text { to } 96 \mathrm{hpf} \text { and the results showed reduced } \\
\text { body length, flexure, microcephaly, abnormal coiling of the gut and edema after } \\
\text { exposure to } 20 \mu \mathrm{M} \text { of NP or BPA or } 10 \mu \mathrm{M} \text { of E2. The genes responsible for } \\
\text { teratogenicity, such as XIRG, skeletal tropomyosin, HGF, cyclin G1, troponin C2, and } \\
\text { ribosomal protein L9 was also studied. The results confirmed the teratogenic effect } \\
\text { exerted by BPA on X. leavis embryos. }\end{array}$ & $\begin{array}{l}\text { Sone et al., } \\
2004[64]\end{array}$ \\
\hline 11. & $\begin{array}{l}\text { Nile tilapia, } \\
\text { Oreochromis } \\
\text { niloticus }(\mathrm{L} .)\end{array}$ & $\begin{array}{l}\text { BPA's potential effects were studied using Nile tilapia, Oreochromis niloticus (L.) } \\
\text { after exposing the fishes to } 0,1.64 \text {, or } 3.28 \mu \mathrm{g} / \mathrm{L} \text { of BPA for six weeks chronically. } \\
\text { The lethal concentration (LC50) was } 13.13 \mu \mathrm{g} / \mathrm{L} \text { of BPA, and the different biochemical } \\
\text { parameters, such as total protein, globulin, albumin, and acetylcholine esterase, were } \\
\text { significantly decreased in level. On the other hand, alanine transferase, aspartate } \\
\text { transferase, alkaline phosphate, creatinine, and uric acid level enhanced significantly } \\
\text { in a dose-dependent manner after BPA exposure. Malondialdehyde level, a marker of } \\
\text { lipid peroxidation, catalase, and superoxide dismutase, significantly increased, } \\
\text { whereas the glutathione S-transferase and glutathione peroxidase were increased } \\
\text { decreased with an increase in the exposure dose of BPA. The study concluded that the } \\
\text { fishes' health conditions deteriorated through impaired kidney and liver function in an } \\
\text { aquatic environment containing BPA. }\end{array}$ & $\begin{array}{l}\text { Tawwab et } \\
\text { al., } 2018 \text { [65] }\end{array}$ \\
\hline 12. & $\begin{array}{l}\text { Zebrafish } \\
\text { embryo }\end{array}$ & $\begin{array}{l}\text { The effect of BPA exposure on the nervous system and motor behavior was studied } \\
\text { using zebrafish embryos by observing the motor behaviors, larval teratology, muscle } \\
\text { structure, and axonal growth of spinal motoneurons during the different developmental } \\
\text { stages. The results indicated that the exposure to BPA modified the spontaneous } \\
\text { movement, decreased the touch response significantly, and decreased the speed of } \\
\text { swimming triggered by the light response. These changes were observed at doses of } \\
\text { BPA, where there was no teratogenic response observed. BPA was seen to induce } \\
\text { damage in axial muscle at the concentration of } 1-15 \mu \mathrm{M} \text {, and there was a disruption in } \\
\text { the growth of axons in primary and secondary motoneuron at higher concentrations } \\
(15 \mu \mathrm{M}) \text {. BPA was also seen to induce apoptosis, and the results indicated that the } \\
\text { initial ROS formation and DNA damage due to oxidative stress might be responsible } \\
\text { for the above damages. }\end{array}$ & $\begin{array}{l}\text { Wang et al., } \\
2013[66]\end{array}$ \\
\hline
\end{tabular}

The above studies have demonstrated the role of BPA in humans, plants, and aquatic organisms. Some studies have also shown the remedial measures for BPA toxicity using some natural compounds. Chicken embryos were taken for the study and exposed to BPA (200 ppm) at 4 days post-fertilization. They administered Zataria multiflora, as a protective agent $6 \mathrm{~h}$ before treating with BPA, and after 20 days, the brain of the treated embryos was studied for different biochemical parameters showing that there was inhibition in the lipid peroxidation enhancement and decrease in total antioxidant levels and GSH. The control embryos were treated with olive oil. The study's finding showed that Zataria multiflora could revert the oxidative damage caused by BPA [67]. In another study, the protective effect of Rosewater and clove oil against BPA-induced toxicity was demonstrated in Sprague-Dawley rats. Three times a week, the rats were orally fed with the different BPA concentrations for 6 weeks along with rose water and clove oil. The only BPA-fed rats had a significant decrease in male hormones like testosterone, FSH and a significant increase in female hormones like estrogen, progesterone and prolactin. The different biochemical parameters and histological studies 
demonstrated that the combination of clove oil and rose water could improve the changes caused by BPA [68]. The removal of BPA from the environment was also accomplished using low-cost adsorbents made from the palm's oil palm trunk and shell. The different physicochemical parameters like $\mathrm{pH}$, the temperature was standardized for BPA adsorption, and $\mathrm{pH}$ value of 3 and temperature $25{ }^{\circ} \mathrm{C}$ was found to be optimum for maximum BPA adsorption from the environment [69]. In another study, BPA removal was explored using a banana bunch and coconut bunch at a temperature of $25^{\circ} \mathrm{C}$ and $\mathrm{pH} 3$ with an exothermic reaction [70]. For removing BPA from the environment, nano nickel catalysts are used for BPA degradation and generate electricity using biofuel cells [71]. The different analogs of BPA are also detrimental to health and the environment and have been discussed recently [72].

\section{Conclusions}

Being an endocrine disrupter, BPA has been a known pollutant for a long time. Not many strict measures have been taken to control the release of such toxicants in the environment. In this review, we have discussed the different routes of BPA exposure to humans and the environmental flora and fauna. The effect of human health due to BPA exposure demonstrated the effect on reproductive functions as well as compromising the immune system. There was also much evidence showing the neurological defects and kidney dysfunction that can arise due to BPA exposure to humans. Environmental effects of BPA were also elaborately reported here, presenting the effect on plants and aquatic vertebrates, and invertebrates. The suppression of immune function was observed by lowered gene expression associated with immune response in some of the studies. In fishes and other aquatic organisms, the production of eggs and sperms has been influenced due to BPA exposure indicating the influence on reproductive health. In this aspect, it is highly warranted that in the future, we have to be very much alert on the use of BPA-containing products as well consumption of food items packaged in BPA-containing plastics. The environmental threat can also be addressed by introducing BPA degrading microorganisms in various water bodies and creating an aerobic environment to accomplish their action successfully.

\section{Funding}

This research received no external funding.

\section{Acknowledgments}

The authors are grateful to the Chettinad Academy of Research and Education, Kelambakkam, Tamilnadu, India, for providing the infrastructural support. We also thank Kanchrapara College under the University of Kalyani, Nadia, West Bengal, India, for supporting us.

\section{Conflicts of Interest}

The authors declare no conflict of interest.

\section{References}

1. Metz, C.M. Bisphenol A: understanding the controversy. Workplace Health Saf 2016, 64, 28-36, https://doi.org/10.1177/2165079915623790. 
2. Yang, L.; Chen, Y.; Shen, Y.; Yang, M.; Li, X.; Han, X.; Jiang, X.; Zhao, B. SERS strategy based on the modified Au nanoparticles for highly sensitive detection of bisphenol A residues in milk. Talanta 2018, 179, 37-42. https://doi.org/10.1016/j.talanta.2017.10.055.

3. Almeida, S.; Raposo, A.; Almeida-González, M.; Carrascosa, C. Bisphenol A: Food exposure and impact on human health. Comprehensive Reviews in Food Science and Food Safety 2018, 17, 1503-1517, https://doi.org./10.1111/1541-4337.12388.

4. Wang, Z.; Cui, H.; Xia, J.; Han, Q.; Lv, N.; Gao, J.; Guo, X.; Zhang, F.; Ma, J.; Su, G. A novel method for bisphenol A analysis in dairy products using graphene as an adsorbent for solid phase extraction followed by ion chromatography. Food Analytical Methods 2013, 6, 1537-1543, https://doi.org/10.1007/s12161-0139567-y.

5. Ahmad, A.; Huei, L.C. Physical and Electrochemical Characterization of Modified Graphite NanoparticlesPhosphotungstic Acid-Nafion on Glassy Carbon Electrode for Bisphenol A Determination. Biointerface Research in Applied Chemistry 2021, 11, 9266- 9277.

6. Huang, Y.; Wong, C.; Zheng, J.; Bouwman, H.; Barra, R.; Wahlström, B.; Neretin, L.; Wong, M.H. Bisphenol A (BPA) in China: a review of sources, environmental levels, and potential human health impacts. Environ. Int. 2012, 42, 91-99, https://doi.org/10.1016/j.envint.2011.04.010.

7. González-Parra, E.; Herrero, J.A.; Elewa, U.; Bosch, R.J.; Arduán, A.O.; Egido, J. Bisphenol a in chronic kidney disease. International journal of nephrology 2013, 2013, https://doi.org/10.1155/2013/437857.

8. Krieter, D.H.; Canaud, B.; Lemke, H.D.; Rodriguez, A.; Morgenroth, A.; von Appen, K.; Dragoun, G.P.; Wanner, C. B isphenol A in Chronic Kidney Disease. Artif. Organs 2013, 37, 283-290, https://doi.org/10.1111/j.1525-1594.2012.01556.x.

9. Liao, C.; Kannan, K. High levels of bisphenol A in paper currencies from several countries, and implications for dermal exposure. Environ. Sci. Technol 2011, 45, 6761-6768. https://doi.org/10.1021/es200977t.

10. Melzer, D.; Osborne, N.J.; Henley, W.E.; Cipelli, R.; Young, A.; Money, C.; McCormack, P.; Luben, R.; Khaw, K.-T.; Wareham, N.J. Urinary bisphenol A concentration and risk of future coronary artery disease in apparently healthy men and women. Circulation 2012, 125, 1482-1490, https://doi.org/10.1161/CIRCULATIONAHA.111.069153.

11. Shankar, A.; Teppala, S.; Sabanayagam, C. Bisphenol A and peripheral arterial disease: results from the NHANES. Environ. Health Perspect 2012, 120, 1297-1300, https://doi.org/10.1289/ehp.1104114.

12. Moriyama, K.; Tagami, T.; Akamizu, T.; Usui, T.; Saijo, M.; Kanamoto, N.; Hataya, Y.; Shimatsu, A.; Kuzuya, H.; Nakao, K. Thyroid hormone action is disrupted by bisphenol A as an antagonist. The Journal of Clinical Endocrinology \& Metabolism 2002, 87, 5185-5190, https://doi.org/10.1210/jc.2002-020209.

13. Yang, Y.-J.; Hong, Y.-P.; Chae, S.A. Reduction in semen quality after mixed exposure to bisphenol A and isobutylparaben in utero and during lactation periods. Hum. Exp. Toxicol 2016, 35, 902-911, https://doi.org/10.1177/0960327115608927.

14. Rodríguez-Carrillo, A.; Mustieles, V.; Pérez-Lobato, R.; Molina-Molina, J.M.; Reina-Pérez, I.; Vela-Soria, F.; Rubio, S.; Olea, N.; Fernández, M.F. Bisphenol A and cognitive function in school-age boys: Is BPA predominantly related to behavior? Neurotoxicology $\mathbf{2 0 1 9}, \quad 74, \quad 162-171$, https://doi.org/10.1016/j.neuro.2019.06.006.

15. Zhou, C.; Wang, W.; Peretz, J.; Flaws, J.A. Bisphenol A exposure inhibits germ cell nest breakdown by reducing apoptosis in cultured neonatal mouse ovaries. Reprod. Toxicol 2015, 57, 87-99, https://doi.org/10.1016/j.reprotox.2015.05.012.

16. Lang, I.A.; Galloway, T.S.; Scarlett, A.; Henley, W.E.; Depledge, M.; Wallace, R.B.; Melzer, D. Association of urinary bisphenol A concentration with medical disorders and laboratory abnormalities in adults. JAMA 2008, 300, 1303-1310, https://doi.org/10.1001/jama.300.11.1303.

17. Rochester, J.R. Bisphenol A and human health: a review of the literature. Reprod. Toxicol 2013, 42, 132-155, https://doi.org/10.1016/j.reprotox.2013.08.008.

18. Hengstler, J.; Foth, H.; Gebel, T.; Kramer, P.-J.; Lilienblum, W.; Schweinfurth, H.; Völkel, W.; Wollin, K.M.; Gundert-Remy, U. Critical evaluation of key evidence on the human health hazards of exposure to bisphenol A. Crit. Rev. Toxicol 2011, 41, 263-291, https://doi.org/10.3109/10408444.2011.558487.

19. Inadera, H. Neurological effects of bisphenol A and its analogues. Int. J. Med. Sci. 2015, 12, 926, https://doi.org/10.7150/ijms.13267.

20. Fenichel, P.; Chevalier, N.; Brucker-Davis, F. Bisphenol A: an endocrine and metabolic disruptor. Ann. Endocrinol (Paris) 2013, 74, 211-220, https://doi.org/10.1016/j.ando.2013.04.002. 
21. Kumar, A.; Gupta, K.; Tomer, V.; Kaur, A.; Kumar, V. Bisphenols as Human Health Hazard: A Systematic Review on Potent Sources, Route of Exposure, Harmful Effects and Safe Alternatives. Toxicol. Int. 2018, 25, 78-92, https://doi.org/10.18311/ti/2018/22303.

22. Preethi, S.; Sandhya, K.; Lebonah, D.E.; Prasad, C.V.; Sreedevi, B.; Chandrasekhar, K.; Kumari, J.P. Toxicity of bisphenol a on humans: a review. International Letters of Natural Sciences 2014, 22, https://www.scipress.com/ILNS.27.32.

23. Chouhan, S.; Yadav, S.K.; Prakash, J.; Singh, S.P. Effect of Bisphenol A on human health and its degradation by microorganisms: a review. Ann. Microbiol 2014, 64, 13-21, https://doi.org/10.1007/s13213-013-0649-2.

24. Gorecki, S.; Bemrah, N.; Roudot, A.-C.; Marchioni, E.; Le Bizec, B.; Faivre, F.; Kadawathagedara, M.; Botton, J.; Rivière, G.; Group, E.M.-C.C.S. Human health risks related to the consumption of foodstuffs of animal origin contaminated by bisphenol A. Food Chem. Toxicol 2017, 110, 333-339, https://doi.org/10.1016/j.fct.2017.10.045.

25. Dumitrascu, M.C.; Mares, C.; Petca, R.-C.; Sandru, F.; Popescu, R.-I.; Mehedintu, C.; Petca, A. Carcinogenic effects of bisphenol A in breast and ovarian cancers. Oncol. Lett. 2020, 20, 1-1, https://doi.org/10.3892/ol.2020.12145.

26. Cimmino, I.; Fiory, F.; Perruolo, G.; Miele, C.; Beguinot, F.; Formisano, P. Potential Mechanisms of Bisphenol A (BPA) Contributing to Human Disease. Int. J. Mol. Sci. 2020, 21, 5761.

27. Matuszczak, E.; Komarowska, M.D.; Debek, W.; Hermanowicz, A. The impact of bisphenol A on fertility, reproductive system, and development: a review of the literature. Int. J. Endocrinol 2019, 2019, https://doi.org/10.1155/2019/4068717.

28. Ma, Y.; Liu, H.; Wu, J.; Yuan, L.; Wang, Y.; Du, X.; Wang, R.; Marwa, P.W.; Petlulu, P.; Chen, X. The adverse health effects of bisphenol A and related toxicity mechanisms. Environ. Res. 2019, 176, 108575, https://doi.org/10.1016/j.envres.2019.108575.

29. Andújar, N.; Gálvez-Ontiveros, Y.; Zafra-Gómez, A.; Rodrigo, L.; Álvarez-Cubero, M.J.; Aguilera, M.; Monteagudo, C.; Rivas, A. Bisphenol A analogues in food and their hormonal and obesogenic effects: a review. Nutrients 2019, 11, 2136.

30. Ghosh, P.; Roy, S.S.; Begum, M.; Ghosh, S. Bisphenol A: Understanding Its Health Effects from the Studies Performed on Model Organisms. In Bisphenol A Exposure and Health Risks, IntechOpen: 2017, https://doi.org/10.5772/intechopen.68971.

31. Huang, D.; Wu, J.; Su, X.; Yan, H.; Sun, Z. Effects of low dose of bisphenol A on the proliferation and mechanism of primary cultured prostate epithelial cells in rodents. Oncol. Lett. 2017, 14, 2635-2642, https://doi.org/10.3892/ol.2017.6469.

32. Chioccarelli, T.; Manfrevola, F.; Migliaccio, M.; Altucci, L.; Porreca, V.; Fasano, S.; Cobellis, G. FetalPerinatal Exposure to Bisphenol-A Affects Quality of Spermatozoa in Adulthood Mouse. Int. J. Endocrinol. 2020, 2020, https://doi.org/10.1155/2020/2750501.

33. Corrales, J.; Kristofco, L.A.; Steele, W.B.; Yates, B.S.; Breed, C.S.; Williams, E.S.; Brooks, B.W. Global assessment of bisphenol A in the environment: review and analysis of its occurrence and bioaccumulation. Dose-Response 2015, 13, 1559325815598308, https://doi.org/10.1177/1559325815598308.

34. Dorn, P.B.; Chou, C.-S.; Gentempo, J.J. Degradation of bisphenol A in natural waters. Chemosphere 1987, 16, 1501-1507.

35. Mohapatra, D.P.; Brar, S.K.; Tyagi, R.D.; Surampalli, R.Y. Occurrence of bisphenol A in wastewater and wastewater sludge of CUQ treatment plant. Journal of Xenobiotics 2011, 1, e3-e3, https://doi.org/10.4081/xeno.2011.e3.

36. Meesters, R.J.; Schröder, H.F. Simultaneous determination of 4-nonylphenol and bisphenol A in sewage sludge. Anal. Chem. 2002, 74, 3566-3574, https://doi.org/10.1021/ac011258q.

37. Crain, D.A.; Eriksen, M.; Iguchi, T.; Jobling, S.; Laufer, H.; LeBlanc, G.A.; Guillette Jr, L.J. An ecological assessment of bisphenol-A: evidence from comparative biology. Reprod. Toxicol. 2007, 24, 225-239, https://doi.org/10.1016/j.reprotox.2007.05.008.

38. Voordeckers, J.W.; Fennell, D.E.; Jones, K.; Häggblom, M.M. Anaerobic biotransformation of tetrabromobisphenol A, tetrachlorobisphenol A, and bisphenol A in estuarine sediments. Environ. Sci. Technol. 2002, 36, 696-701, https://doi.org/10.1021/es011081h.

39. Borrirukwisitsak, S.; Keenan, H.E.; Gauchotte-Lindsay, C. Effects of salinity, pH and temperature on the octanol-water partition coefficient of bisphenol A. International Journal of Environmental Science and Development 2012, 3, 460, https://doi.org/10.7763/IJESD.2012.V3.267. 
40. Geens, T.; Aerts, D.; Berthot, C.; Bourguignon, J.-P.; Goeyens, L.; Lecomte, P.; Maghuin-Rogister, G.; Pironnet, A.-M.; Pussemier, L.; Scippo, M.-L. A review of dietary and non-dietary exposure to bisphenol-A. Food Chem. Toxicol. 2012, 50, 3725-3740, https://doi.org/10.1016/j.fct.2012.07.059.

41. Vanstraelen, M.; Benková, E. Hormonal interactions in the regulation of plant development. Annu. Rev. Cell Dev. Biol. 2012, 28, 463-487, https://doi.org/10.1146/annurev-cellbio-101011-155741.

42. Qiu, Z.; Wang, L.; Zhou, Q. Effects of bisphenol A on growth, photosynthesis and chlorophyll fluorescence in above-ground organs of soybean seedlings. Chemosphere 2013, 90, 1274-1280, https://doi.org/10.1016/j.chemosphere.2012.09.085.

43. Li, X.; Wang, L.; Wang, S.; Yang, Q.; Zhou, Q.; Huang, X. A preliminary analysis of the effects of bisphenol A on the plant root growth via changes in endogenous plant hormones. Ecotoxicol. Environ. Saf. 2018, 150, 152-158, https://doi.org/10.1016/j.ecoenv.2017.12.031.

44. Vishwakarma, K.; Upadhyay, N.; Kumar, N.; Yadav, G.; Singh, J.; Mishra, R.K.; Kumar, V.; Verma, R.; Upadhyay, R.; Pandey, M. Abscisic acid signaling and abiotic stress tolerance in plants: a review on current knowledge and future prospects. Frontiers in plant science 2017, 8, 161, https://doi.org/10.3389/fpls.2017.00161.

45. Jiao, L.; Ding, H.; Wang, L.; Zhou, Q.; Huang, X. Bisphenol A effects on the chlorophyll contents in soybean at different growth stages. Environ. Pollut. 2017, 223, 426-434, https://doi.org/10.1016/j.envpol.2017.01.042.

46. Wu, N.C.; Seebacher, F. Effect of the plastic pollutant bisphenol A on the biology of aquatic organisms: A meta-analysis. Glob. Chang. Biol. 2020, https://doi.org/10.1111/gcb.15127.

47. Franzellitti, S.; Canesi, L.; Auguste, M.; Wathsala, R.H.; Fabbri, E. Microplastic exposure and effects in aquatic organisms: A physiological perspective. Environ. Toxicol. Pharmacol. 2019, 68, 37-51, https://doi.org/10.1016/j.etap.2019.03.009.

48. Bhandari, R.K.; Deem, S.L.; Holliday, D.K.; Jandegian, C.M.; Kassotis, C.D.; Nagel, S.C.; Tillitt, D.E.; Vom Saal, F.S.; Rosenfeld, C.S. Effects of the environmental estrogenic contaminants bisphenol A and 17 $\alpha$-ethinyl estradiol on sexual development and adult behaviors in aquatic wildlife species. Gen. Comp. Endocrinol. 2015, 214, 195-219, https://doi.org/10.1016/j.ygcen.2014.09.014.

49. Canesi, L.; Fabbri, E. Environmental effects of BPA: focus on aquatic species. Dose-Response 2015, 13, 1559325815598304, https://doi.org/10.1177/1559325815598304.

50. Flint, S.; Markle, T.; Thompson, S.; Wallace, E. Bisphenol A exposure, effects, and policy: a wildlife perspective. J. Environ. Manage. 2012, 104, 19-34, https://doi.org/10.1016/j.jenvman.2012.03.021.

51. Mathieu-Denoncourt, J.; Wallace, S.J.; de Solla, S.R.; Langlois, V.S. Plasticizer endocrine disruption: Highlighting developmental and reproductive effects in mammals and non-mammalian aquatic species. Gen. Comp. Endocrinol. 2015, 219, 74-88, https://doi.org/10.1016/j.ygcen.2014.11.003.

52. Oehlmann, J.; Schulte-Oehlmann, U.; Kloas, W.; Jagnytsch, O.; Lutz, I.; Kusk, K.O.; Wollenberger, L.; Santos, E.M.; Paull, G.C.; Van Look, K.J. A critical analysis of the biological impacts of plasticizers on wildlife. Philosophical Transactions of the Royal Society B: Biological Sciences 2009, 364, 2047-2062.

53. Pickford, D.B.; Hetheridge, M.J.; Caunter, J.E.; Hall, A.T.; Hutchinson, T.H. Assessing chronic toxicity of bisphenol A to larvae of the African clawed frog (Xenopus laevis) in a flow-through exposure system. Chemosphere 2003, 53, 223-235, https://doi.org/10.1016/s0045-6535(03)00308-4.

54. Oehlmann, J.; Schulte-Oehlmann, U.; Bachmann, J.; Oetken, M.; Lutz, I.; Kloas, W.; Ternes, T.A. Bisphenol A induces superfeminization in the ramshorn snail (Gastropoda: Prosobranchia) at environmentally relevant concentrations. Environ. Health Perspect 2006, 114, 127-133, https://doi.org/10.1289/ehp.8065.

55. Dong, X.; Zhang, Z.; Meng, S.; Pan, C.; Yang, M.; Wu, X.; Yang, L.; Xu, H. Parental exposure to bisphenol A and its analogs influences zebrafish offspring immunity. Sci. Total Environ. 2018, 610, 291-297, https://doi.org/10.1016/j.scitotenv.2017.08.057.

56. Yang, M.; Qiu, W.; Chen, B.; Chen, J.; Liu, S.; Wu, M.; Wang, K.-J. The in vitro immune modulatory effect

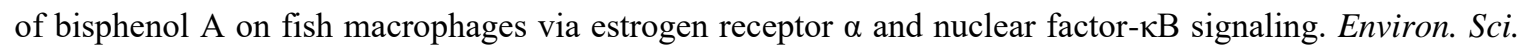
Technol. 2015, 49, 1888-1895, https://doi.org/10.1021/es505163v.

57. Minghong, W.; Hai, X.; Ming, Y.; Gang, X. Effects of chronic bisphenol A exposure on hepatic antioxidant parameters in medaka (Oryzias latipes). Toxicol. Environ. Chem. 2011, 93, 270-278, https://doi.org/10.1080/02772248.2010.530136.

58. Park, S.-Y.; Choi, J. Genotoxic effects of nonylphenol and bisphenol A exposure in aquatic biomonitoring species: freshwater crustacean, Daphnia magna, and aquatic midge, Chironomus riparius. Bull. Environ. Contam. Toxicol. 2009, 83, 463-468, https://doi.org/10.1007/s00128-009-9745-1. 
59. Planelló, R.; Martínez-Guitarte, J.; Morcillo, G. The endocrine disruptor bisphenol A increases the expression of HSP70 and ecdysone receptor genes in the aquatic larvae of Chironomus riparius. Chemosphere 2008, 71, 1870-1876, https://doi.org/10.1016/j.chemosphere.2008.01.033.

60. Wang, Q.; Yang, H.; Yang, M.; Yu, Y.; Yan, M.; Zhou, L.; Liu, X.; Xiao, S.; Yang, Y.; Wang, Y. Toxic effects of bisphenol A on goldfish gonad development and the possible pathway of BPA disturbance in female and male fish reproduction. Chemosphere 2019, 221, 235-245, https://doi.org/10.1016/j.chemosphere.2019.01.033.

61. Qiu, W.; Shen, Y.; Pan, C.; Liu, S.; Wu, M.; Yang, M.; Wang, K.-J. The potential immune modulatory effect of chronic bisphenol A exposure on gene regulation in male medaka (Oryzias latipes) liver. Ecotoxicol. Environ. Saf. 2016, 130, 146-154, https://doi.org/10.1016/j.ecoenv.2016.04.015.

62. Qiu, W.; Chen, J.; Li, Y.; Chen, Z.; Jiang, L.; Yang, M.; Wu, M. Oxidative stress and immune disturbance after long-term exposure to bisphenol A in juvenile common carp (Cyprinus carpio). Ecotoxicol. Environ. Saf. 2016, 130, 93-102, https://doi.org/10.1016/j.ecoenv.2016.04.014.

63. Tao, S.; Zhang, Y.; Yuan, C.; Gao, J.; Wu, F.; Wang, Z. Oxidative stress and immunotoxic effects of bisphenol A on the larvae of rare minnow Gobiocypris rarus. Ecotoxicol Environ Saf. 2016, 124, 377-385, https://doi.org/10.1016/j.ecoenv.2015.11.014.

64. Sone, K.; Hinago, M.; Kitayama, A.; Morokuma, J.; Ueno, N.; Watanabe, H.; Iguchi, T. Effects of 17 $\beta$ estradiol, nonylphenol, and bisphenol-A on developing Xenopus laevis embryos. Gen. Comp. Endocrinol. 2004, 138, 228-236, https://doi.org/10.1016/j.ygcen.2004.06.011.

65. Hamed, H.S.; Abdel-Tawwab, M. Ameliorative effect of propolis supplementation on alleviating bisphenolA toxicity: Growth performance, biochemical variables, and oxidative stress biomarkers of Nile tilapia, Oreochromis niloticus (L.) fingerlings, Comparative Biochemistry and Physiology Part C: Toxicology \& Pharmacology 2017, 202, 63-69, https://doi.org/10.1016/j.cbpc.2017.08.001.

66. Wang, X.; Dong, Q.; Chen, Y.; Jiang, H.; Xiao, Q.; Wang, Y.; Li, W.; Bai, C.; Huang, C.; Yang, D. Bisphenol A affects axonal growth, musculature and motor behavior in developing zebrafish. Aquat. Toxicol. 2013, 142, 104-113, https://doi.org/10.1016/j.aquatox.2013.07.011.

67. Najafi, P.Z.; Ashrafizadeh, M.; Farkhondeh, T.; Peivasteh-Roudsari, L.; Samarghandian, S. The protective effect of Zataria Multiflora on the embryotoxicity induced by bisphenol A in the brain of chicken embryos. Biointerface research in applied chemistry 2019, 9, 4239-4242.

68. Osman, M.A.; Mahmoud, G.I.; Elgammal, M.H.; Hasan, R.S. Bisphenol a Hormonal Disrupture and Preventive Effect of Rose Water and Clove Oil. Biointerface research in applied chemistry 2021, 11, 8780 8803, https://doi.org/10.33263/BRIAC112.87808803.

69. Kristanti, R.; Hadibarata, T.; Al Qahtani, H. Adsorption of bisphenol A on oil palm biomass activated carbon: characterization, isotherm, kinetic and thermodynamic studies. Biointerface Research in Applied Chemistry 2019, 9, 4217-4224.

70. Lazim, Z. M.; Salmiati; Hadibarata, T.; Yusop, Z.; Nazifa, T. H.; Abdullah, N. H.; Nuid, M.; Salim, N. A. A.; Zainuddin, N. A.; Ahmad, N. Bisphenol A Removal by Adsorption Using Waste Biomass: Isotherm and Kinetic Studies. Biointerface Research in Applied Chemistry 2021, 11, 8467-8481.

71. Fan, Z.; Yu, B.; Xu, W.; Wu, X.; Yang, X.; Zheng, H.; Wu, Z. Nano-nickel catalyst for the oxidation of bisphenol A to generate electricity via a fuel cell. Biointerface Research in Applied Chemistry 2016, 6, 18371841.

72. Mustieles, V.; d'Cruz, S.C.; Couderq, S.; Rodríguez-Carrillo, A.; Fini, J.-B.; Hofer, T.; Steffensen, I.-L.; Dirven, H.; Barouki, R.; Olea, N. Bisphenol A and its analogues: a comprehensive review to identify and prioritize effect biomarkers for human biomonitoring. Environ. Int. 2020, 144, 105811, https://doi.org/10.1016/j.envint.2020.105811. 